\title{
Jokro: The death of a wild infant chimpanzee from respiratory disease
}

\author{
Tetsuro Matsuzawa ${ }^{1,2,3}$
}

Published online: 26 April 2020

(C) Japan Monkey Centre and Springer Japan KK, part of Springer Nature 2020

\section{COVID-19 pandemic and Ebola in Guinea}

This article aims to summarize reports of flu-like diseases in wild chimpanzees and introduce the full story of an infant chimpanzee who taught us a great deal about death and the dying process. In times of disease outbreaks, we are often overwhelmed by the sheer number of deaths: we pay attention to the total count only and forget that there is an individual patient's story behind each number that is added. However, I believe that every single case is unique and important in its own right. Here, I will try to underscore this point by providing a narrative for the life and death of a chimpanzee I got to know in the wild (Fig. 1).

The outbreak of COVID-19 began at the end of 2019 and became a pandemic in 2020. According to the Johns Hopkins University Corona Virus Resource Center (https://coronavirus.jhu.edu/), the number of total confirmed infections exceeded 1 million as of April 3, 2020. By the end of that day there were 1,011,490 confirmed cases globally, across 180 countries and regions. A total of 210,186 patients had recovered, and the number of deaths stood at 52,863 . The numbers were doubled within 11 days on April 14. All over the world, people are anxious about their friends, families, and colleagues.

The disease is caused by a virus that was tentatively named 2019-nCOV by the World Health Organization (WHO). This virus was formally recognized by the Coronavirus Study Group (CSG), a working group of the International Committee on Taxonomy of Viruses (ICTV), as a

Electronic supplementary material The online version of this article (https://doi.org/10.1007/s10329-020-00819-0) contains supplementary material.

Tetsuro Matsuzawa

matsuzawa.tetsuro.8w@kyoto-u.ac.jp

Kyoto University Institute for Advanced Study, Kyoto, Japan

2 Primate Research Institute, Kyoto University, Inuyama, Japan

3 Chubu University Academy for Emerging Sciences, Kasugai, Japan sister to severe acute respiratory syndrome coronaviruses (SARS-CoVs). Thus, the CSG named it severe acute respiratory syndrome coronavirus 2 (SARS-CoV-2) (Gorbalenya et al. 2020). During the 21st century, several life-threatening viruses were introduced to humans from zoonotic reservoirs: this happened with severe acute respiratory syndrome (SARS) in 2002-2003 and, a decade later, with Middle East respiratory syndrome (MERS) in 2012.

In the case of SARS, which spread primarily in southern China, wild animals such as the masked palm civet (Paguma larvata) (Wang et al. 2005) and the horseshoe bat (Rhinolophus cornutus) (Wang et al. 2006) were the suspected reservoirs for the virus. The current outbreak of COVID-19 also draws attention to the food markets dealing wild animals in Wuhan, China, where the first infected persons were found. Bats, snakes, and pangolins have been suggested as possible reservoirs of the virus.

The COVID-19 outbreak we are facing reminds me of the Ebola outbreak in Guinea a few years ago. Ebola virus disease (EVD), formerly known as Ebola hemorrhagic fever, is a rare but severe, often fatal illness in humans. EVD first appeared in 1976 in a village near the Ebola River, a stream tributary of the Congo River in the Congo Basin, from which

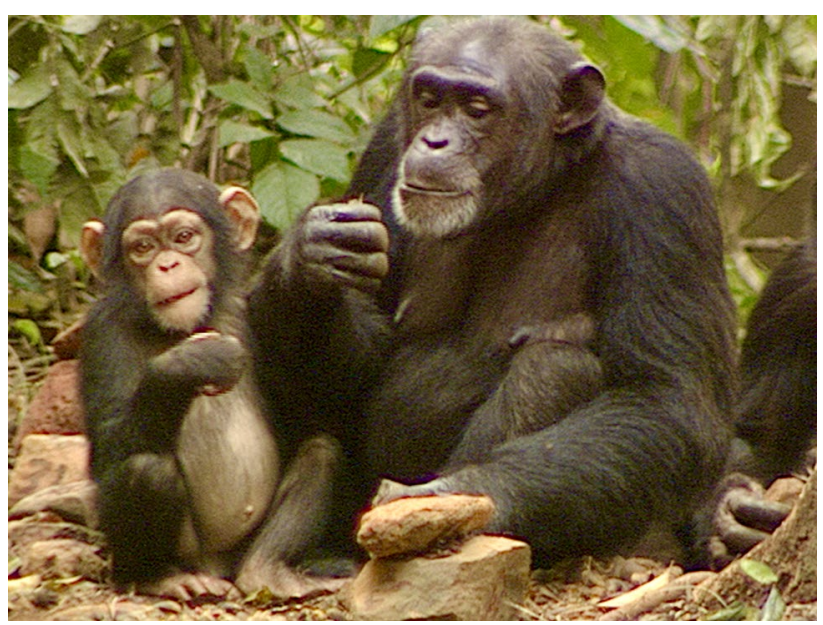

Fig. 1 The infant named Jokro and her mother Jire 
the disease takes its name. The virus is transmitted to people from wild animals and spreads in the human population through human-to-human transmission. The WHO reports the average EVD case fatality rate to be around $50 \%$.

From the end of 2013 to the beginning of 2016, there was an Ebola outbreak in Guinea, where I have been studying wild chimpanzees since 1986. The outbreak in West Africa was the largest Ebola outbreak since the virus was first discovered. The outbreak started in Guinea and then moved to Sierra Leone and Liberia. According to the WHO, the total number of confirmed and probable cases in the three countries reached 17,843, and 11,308 deaths were registered by March 2016. Since African great apes are vulnerable to Ebola as well (Leendertz et al. 2017), we put all fieldwork with wild chimpanzees in Bossou and Nimba on hold for 1.5 years, from April 2014 to November 2015. We also asked the local people not to enter to the forest and asked the Guinean authorities to stop ecotourism to prevent possible transmission from humans to chimpanzees. There were no reported cases of Ebola-related deaths in wild chimpanzees in Guinea during that period.

The virus causing the 2013-2016 West African outbreak belongs to the Zaire ebolavirus species. It is believed that fruit bats of the Pteropodidae family are natural Ebola virus hosts (Leroy et al. 2005). The epidemic that occurred in West Africa stemmed from a single zoonotic transmission event to a 2-year-old boy in Meliandou, Guinea. The index case may have been infected when playing in a hollow tree housing a colony of insectivorous free-tailed bats (Mops condylurus). Bats in this family have previously been discussed as potential sources for Ebola virus outbreaks (Saéz 2015). Assuming that COVID-19 has a natural reservoir in wild animals, now is the time to think again about humans' relationship with and behavior toward wild animals.

\section{Flu-like respiratory diseases in wild chimpanzees and the 2003 epidemic at Bossou}

Respiratory disease is one of the major threats to free-living great apes in the wild. Respiratory disease epidemics have been reported in the past in human-habituated groups of chimpanzees such as those in Gombe, Tanzania (Goodall 1986; Lonsdorf et al. 2006; Wallis and Lee 1999; Williams et al. 2008), Mahale, Tanzania (Hosaka 1995; Hanamura et al. 2006; Kaur et al. 2008), Taï, Côte d'Ivoire (Boesch 2008; Köndgen 2008), Kanyawara and Ngogo in Kibale, Uganda (Scully et al. 2018; Thompson et al. 2018; Negrey et al. 2019), and in Bossou, Guinea (Humle 2011). In each of these cases, the respiratory disease must have been transmitted from humans to wild chimpanzees.
In Gombe, Tanzania (Williams et al. 2008), the researchers analyzed 47 years of data from 1960 to 2006 on the Kasekela community in Gombe National Park. Community size fluctuated between 38 and 60 . From records on 220 chimpanzees and 130 deaths, they found that the most important cause of mortality was illness (58\% of deaths with known cause), followed by intraspecific aggression (20\% of deaths with known cause). Most deaths due to illness occurred during epidemics, and the most common category of disease was respiratory.

In Taï, Côte d'Ivoire (Köndgen 2008), when five distinct respiratory outbreaks hit three communities of habituated chimpanzees in 1999, 2004 (twice in south group), 2005, and 2006, the researchers made systematic clinical observations. Morbidity was high in the outbreaks, with an average of $92 \%$ of individuals showing clinical symptoms, including elevated breathing rate, conspicuous breathing sounds, breathing with mouth open, sneezing, and either dry or humid cough. Heavily affected animals showed a decrease in daily food intake and signs of weakness such as increased resting time and decreased ability to keep up with other animals or to sustain physical activity.

In Kanyawara-Kibale, Uganda (Scully et al. 2018), when a lethal respiratory outbreak happened in 2013, the researchers concluded that the molecular and epidemiologic analyses implicated human rhinovirus $\mathrm{C}$ as the cause. Postmortem samples from an infant chimpanzee yielded near-complete genome sequences throughout the respiratory tract; other pathogens were absent. Rhinoviruses are antigenically diverse members of the family Picornaviridae, genus Enterovirus, which cause the common cold in humans.

In Kanyawara and Ngogo in Kibale, Uganda (Nergey 2019), the researchers reported simultaneous outbreaks of two distinct human respiratory viruses, human metapneumovirus (MPV; Pneumoviridae: Metapneumovirus) and human respirovirus 3 (HRV3; Paramyxoviridae; Respirovirus, formerly known as parainfluenza virus 3 ), in two chimpanzee communities, Ngogo and Kanyawara, in the same forest of Kibale in Uganda in December 2016 and January 2017. The viruses were absent before the outbreaks, but each was present in ill chimpanzees from one community during the outbreak period. The results suggested two independent and simultaneous reverse zoonotic origins, either directly from humans or via intermediary hosts. The results also caution against assuming common causation in coincident outbreaks.

There is a very important difference between human communities and chimpanzee communities. The transmission of respiratory viruses between chimpanzee communities is probably uncommon, despite high rates of transmission within chimpanzee communities through grooming and social interaction such as touching, sniffing, and open-mouth kissing. In contrast to the prevalence of intra-community 
physical contact, chimpanzees from neighboring communities rarely interact, which may limit opportunities for inter-community transmission even of highly contagious microbes. This point is in clear contrast with the current COVID-19 outbreak in human communities and our human way of life.

In Bossou, Guinea, West Africa, we documented a flu-like epidemic from November to December 2003 (Matsuzawa et al. 2004; Matsuzawa 2006; Humle 2011). At the time, the Bossou chimpanzee community numbered 19 individuals. Morbidity was $84 \%$ ( 16 out of 19 individuals) while mortality rate was $26 \%$ (five out of 19). We lost five chimpanzees in total: two old females (Kai and Nina), two infants (1.5-yearold Jimato and 2.5-year-old Veve), and one young male of 10 years (Poni). According to Tatyana Humle (Humle 2011), there was a notable precursor event. On November 13, 2003, a group of tourists visited Bossou. Two male chimpanzees (Yolo and Poni), the most habituated members of the community at the time, approached the group to within 5-7 m. At the time, tourists were not yet required to wear masks during their outings with chimpanzees.

Nothing happened for 5 days after this encounter with tourists. Then, our local research guides failed to locate any member of the community between the 19th and the 23rd of November. The chimpanzees were unusually quiet and therefore extremely difficult to locate by local assistants and researchers on site. On November 24, we found 14 chimpanzees, all of whom showed symptomatic signs of respiratory disease, such as nasal discharge and coughing. All affected individuals showed a decrease in food intake and physical activity, resting for unusually long periods of time.

Since the 2003 epidemic at Bossou, we have set in place a policy for a minimum observation distance between humans and chimpanzees ( $7 \mathrm{~m}$ for researchers, students, and local staff; $20 \mathrm{~m}$ for tourists), and for the compulsory wearing of face-masks in the forest. We have also made efforts to minimize the prevalence of zoonotic disease in the area. This kind of field policy has been proposed, practiced, and shared by other field sites (Boesch 2008; Humle 2011).

\section{The role of field experiments in routine health monitoring}

Catching a cold or flu-like illness is common in wild chimpanzees. Many have died from respiratory diseases. However, it is very rare to find reports in the literature on the real process of how a respiratory disease progresses in an individual: a chronological account of how the disease begins, develops and ends. Here, I wanted to share my detailed description of the case of an infant chimpanzee named Jokro (Matsuzawa 1997, 2011). I happened to capture her life on videotape for 16 days before her death and 27 days thereafter.

It is very difficult to follow wild chimpanzees day-to-day closely enough to produce a detailed record of behavioral change and of the progress of the disease. However, our field experiments on tool use in Bossou provided an ideal opportunity to monitor the health and behavior of wild chimpanzees routinely: at regular intervals, in the same place, and under the same conditions. My colleagues and I have been running field experiments on stone tool use by wild chimpanzees at a designated site, Bossou's “outdoor laboratory", since 1988 (Matsuzawa 1994; Inoue-Nakamura and Matsuzawa 1997; Biro et al. 2003; Schofield et al. 2019). In this natural clearing in the forest, located on top of a sacred hill, experimental objects (nuts and stones) are provided by experimenters, and chimpanzees crack nuts using stone hammers and anvils. We keep a distance of about $15 \mathrm{~m}$ from the chimpanzees, hiding ourselves behind a grass fence to record their behavior. Bossou chimpanzees often visit the outdoor laboratory spontaneously, as one of many oilpalm nut-cracking sites available in the area.

In January and February 1992, I was in Bossou to study stone-tool use. There happened to be no other researchers or students at the site at the time. I was alone in the outdoor laboratory, waiting each day for the chimpanzees and preparing to video-record their behavior. Through my daily observations, I witnessed the illness, the dying, and the death of an infant chimpanzee who had contracted a respiratory disease (Matsuzawa 1997, 2011). The likely cause of death was a form of bronchitis or pneumonia.

After returning to Japan, I asked my collaborator Miho Nakamura, a documentary filmmaker, to produce a visual archive, assembling and editing the on-site video-recordings into a day-by-day story. She and her team had also filmed three times at Bossou in 1990-91, 1996, and 2000, so she knew all the chimpanzees well. I asked Dora Biro for the English narration: she was a graduate student at Oxford University when she started her fieldwork with Bossou chimpanzees in 1999. The video story was completed in 2003.

To provide comprehensive detail, I have included the 19-min film, entitled "Jokro: the death of an infant chimpanzee", as a supplementary video accompanying this article. It is also available at the following website: https://www.green corridor.info/en/videos/jokro/. There are sister versions of the video in French narrated by Laura Martinez, and English video with Japanese subtitles. Below, I reproduce the English narration in full.

\section{Jokro: the death of an infant chimpanzee}

This is the true story of an infant chimpanzee at Bossou, Guinea, West Africa, who died at the age of two-and-a-half years. A researcher happened to capture her life on videotape 
for 16 days before her death and 27 days thereafter. The mother was named Jire, an approximately 35 -year-old female. The infant's name was Jokro.

In January 1992, I visited the forests of Bossou, in Guinea. At Bossou, there is a long-term research site where we can observe stone-tool use by wild chimpanzees. Here comes a female chimpanzee named Jire. She is carrying her baby on her back. The baby is called Jokro.

January 10. Chimpanzees at Bossou use a pair of stones to crack open oil-palm nuts. Jokro, the baby, sits by her mother's side. She seems to have a runny nose. Right behind Jokro sits her big sister, Ja. Ja is seven-and-a-half years old, and she can already crack open the nuts. Jokro is two-anda-half, and she cannot use the stone tools yet. Instead, she steals nuts from her mother, but it looks like Jokro is not feeling too well. She may have caught a cold. Although the forest is located close to the equator, the temperature drops in January. At night, it can fall below 15 degrees Celsius. Jire puts the back of her fingers against her daughter's forehead. It looks almost as if, being anxious about Jokro, she is checking her body temperature.

January 12. Jokro is riding on her mother's back, and so together they arrive at the nut-cracking site. Chimpanzee infants stay with their mothers until they reach the age of about 5 years. Jokro starts to suckle. She will continue to feed on breast milk until the age of at least three-and-a-half years, even though she can also eat other foods.

January 13. The next day, Jokro's walk is unsteady. If you look carefully, you can see that the hair around her hips is in poor condition. Although Jire, the mother, cracks nuts as usual, Jokro only sits by her side.

January 16. Three days have passed. Jokro's condition is worsening. She is sitting alone, hardly moving, not far from her mother. Ja, Jokro's seven-and-a-half-year-old big sister, walks over to Jokro. She invites her to play. Ja touches Jokro, but Jokro does not respond. So Ja bends a shrub, trying to encourage Jokro to play in this way, but still, Jokro does not move. After cracking nuts, the chimpanzees move on to feed on fruits high up in the trees. As they are moving from one tree to the next, I happen to observe that Jokro's big sister, $\mathrm{Ja}$, is transporting a log. She carries the log on her shoulder, or holds it under her arm. When she stops on a branch, she gently pats the log. To me, this is somehow reminiscent of the toys of young girls native to the area around Bossou, whose dolls consist of a simple straight log with hair attached to the top. It seems as if $\mathrm{Ja}$ is pretending that the $\log$ is her ill little sister, and she is caring for it as her mother cared for Jokro.

January 18. Ten days have passed since Jokro caught a cold. When her mother comes to sit nearby, Jokro slowly approaches her and starts to groom. Infants begin to groom their mother and other members of the community at the age of one-and-a-half years. However, infants are not very good

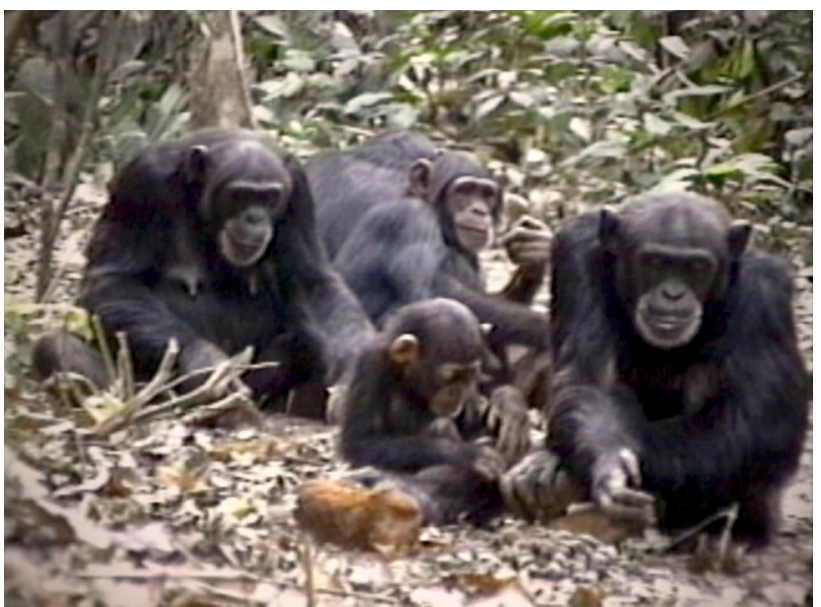

Fig. 2 On Feb 18, Jokro grooms her mother for a long time

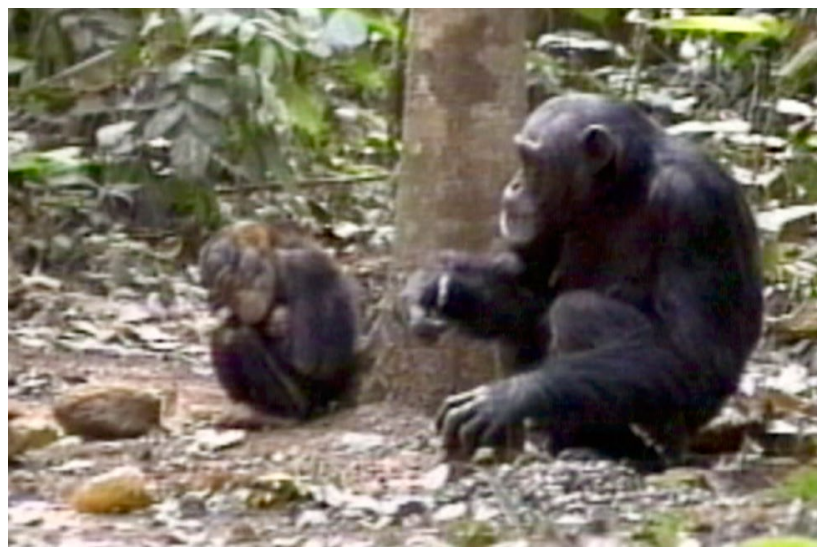

Fig. 3 On Jan 20, Jokro's eyes are closed and her head rests on her bended knees

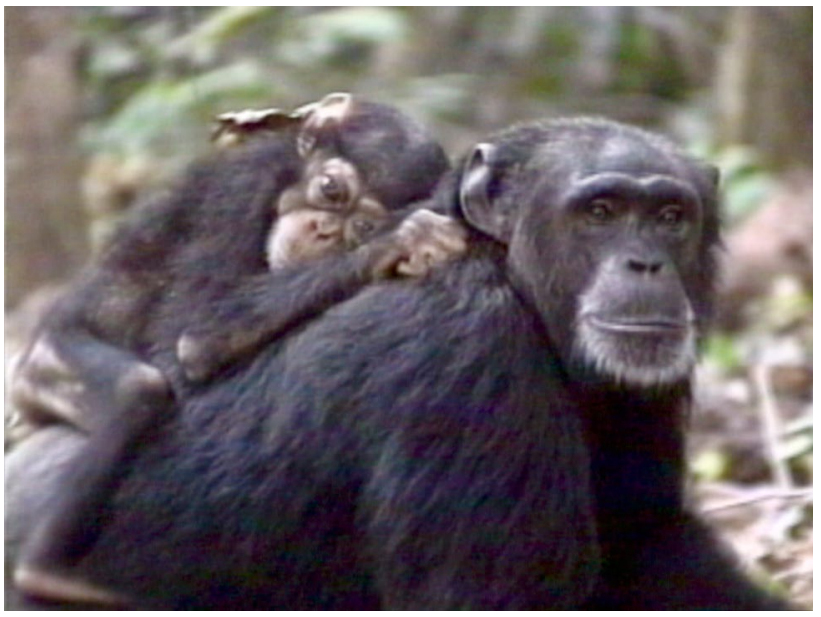

Fig. 4 On Jan 23, Jokro's eyes are still open, and they look straight into mine 
groomers, and so the bouts tend to be short. But, on this day, Jokro grooms her mother for a long time, with eager attention (Fig. 2). Nevertheless, Jokro no longer eats, and does little apart from sit quietly by her mother.

January 19. The next day, Jokro suddenly falls to the ground. Her big sister Ja, walks over to her and tugs at her hand and leg. Ja tries to pull Jokro up, but she does not stir. The group now starts to move. Ja follows the others, and Jire comes to the infant. She gently lifts Jokro onto her back. There seems to be some energy left in Jokro yet. She grasps the hairs on her mother's back as they move away.

January 20. The next day. Jokro's condition has improved a little. She is sitting next to her mother. However, she has stopped suckling. Her eyes are closed and her head rests on her bended knees (Fig. 3).

January 23. Three days later, Jokro's condition has seriously deteriorated. When Jire takes her hand and lifts her onto her back, Jokro just succeeds to cling to her. As they pass in front of me, I see that Jokro's eyes are still open, and they look straight into mine (Fig. 4).

January 25. Jokro's arms and legs hang lifelessly. Jire puts her daughter on the ground. I look at Jokro's chest, but see no signs of breathing. I realize that she is dead-she died this very day. Jire takes Jokro's hand and places her body on her back. She is holding Jokro's wrist between her neck and shoulder. Just like when she was alive, Jokro is "riding" on her mother's back in prone posture (Fig. 5).

January 27. Two days have passed since I confirmed Jokro's death. Her corpse is lying face up, supine posture, on the back of the mother. The belly is swollen with gas. Jokro's body has started to decompose. Jire chases away the flies circling her dead infant.

January 28. Three days after death. Jire continues to carry the body, but its posture has become more strange. It is lying on its back, upside down. The head is facing backwards. Jokro's belly is now flat. The rotting seems to have slowed.

January 29. Four days after death. Jokro's body has begun to dry out-it is mummifying. The shape is becoming distorted. But the mother has returned to carrying it the way she would a live infant-right side up, and in the normal prone position. Tua, the alpha male of the community, sniffs Jokro's corpse. I myself can smell the strong odor of decomposition. However, other members of the community show no signs of aversion to or fear of the lifeless body. When Jire puts the body on the ground, other chimpanzees peer at it curiously. They watch as the mother picks fly larvae off her infant's remains.

February 3. Nine days after death. A fight breaks out within the community. Jire does not release Jokro's hand. She holds her daughter's arm between her neck and shoulder, keeping it safe from falling as she climbs.

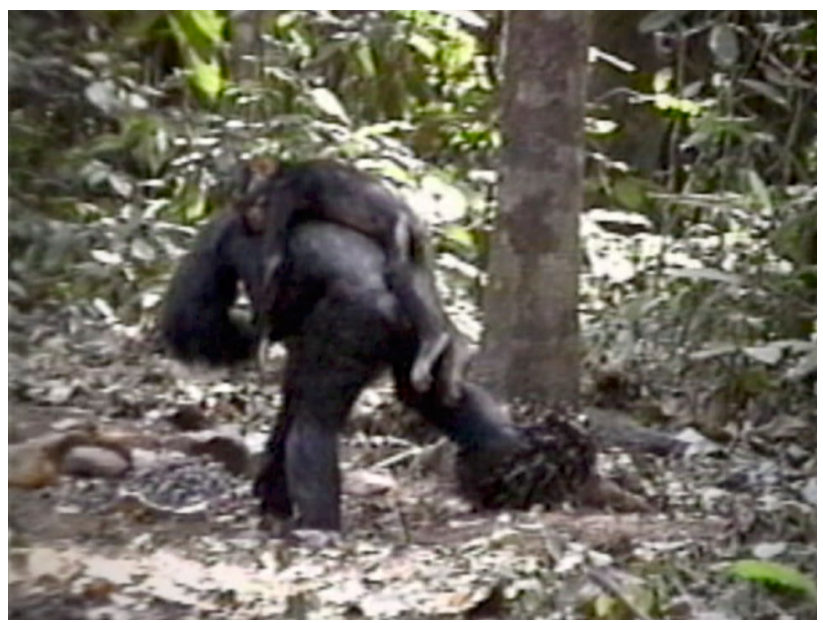

Fig. 5 On Jan 25, Jokro is dead. The mother takes Jokro's hand and places her body on her back

February 9. Fifteen days have passed since Jokro died. Her body has now completely dried out. Jire continues to carry the body cautiously. But now the mother has noticed a change in her own body. Because her infant has died and stopped suckling, Jire's menstrual cycle has returned. Jire continues to chase away the flies attracted to the dead body. Then, she picks up the body and looks directly into its face. She starts to clean Jokro's face. She grooms her daughter's remains as if she were still alive (Fig. 6). Soon after, I observe a youngster playing with the body, while the adults are taking a rest. A six-and-a-half-yearold male, named Na, takes Jokro's body and climbs a tree with it. He swings the corpse and lets it fall to the ground from a height of about $5 \mathrm{~m}$. He rushes down the tree and picks it up, then climbs up and drops it again. He repeats

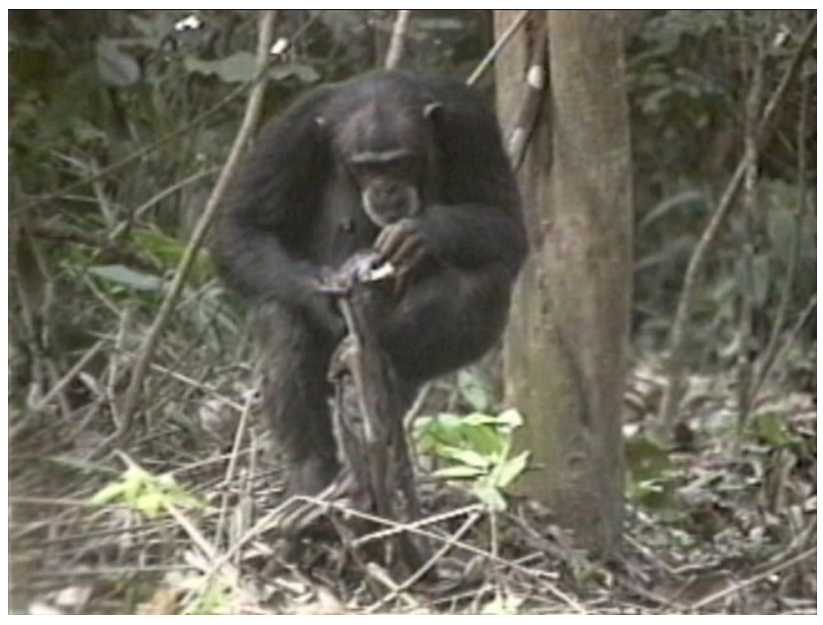

Fig. 6 On Feb 9, the mother grooms her daughter's remains as if she were still alive 
this over and over. It looks like two young chimpanzees playing chase. Meanwhile, Jire looks on gently.

February 15. Twenty-one days after death. Jire's bottom is swollen and pink. This is how a female chimpanzee's body signals the time of ovulation. A five-and-a-half-yearold boy stands up, raises his arms, and shows his penis in a sexual courtship display. It is not unusual for such a young chimpanzee to perform courtship in this way. However, Jire does not abandon her dead infant.

February 17. Twenty-three days after death. One day, a very interesting episode occurs. Tua, the alpha male of the community, rushes toward me in a charging display. He uses Jokro's mummified body as a part of his display. Chimpanzees usually use dead branches to accentuate power in a charging display. Yet this time, Tua uses the body of a dead infant. However, I notice a subtle detail. When Tua turns around, he gently switches the body from his right to left hand. With branches, he has never shown such delicate handling as with Jokro's remains. I sensed an unknown side to him, and others of his kind-a part hiding deep within the chimpanzee's mind. Tua abandons the body right in front of me, only about $5 \mathrm{~m}$ away. Jokro has become a perfect mummy. All her body parts have remained intact—only a jaw is missing. The mother, Jire, retrieves Jokro's body, just as she always has (Fig. 7).

And so an infant chimpanzee lived and died in the forest of Bossou. She was two-and-a-half when her life ended, but I observed how she remained with her community for a month beyond her death. The word "Jokro" comes from the language of the area's native people, the Manon. It is the triplochiton, a huge tree with leaves in the shape of a hand. Perhaps Jokro will be reborn in her next life as her namesake-and live for a 100 years.

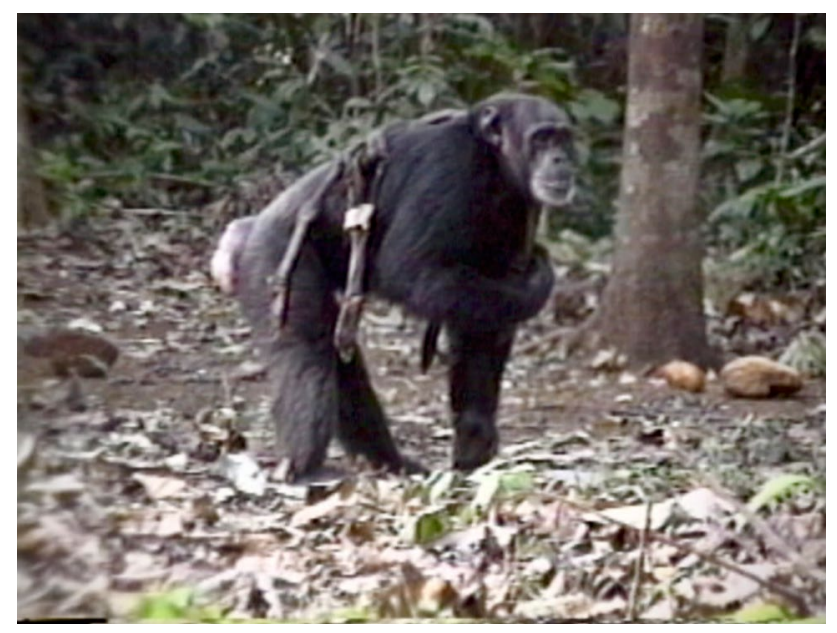

Fig. 7 On Feb 17, the mother continues carrying the corpse

\section{Thanatology: dying and death in social contexts}

The story of Jokro in 1992 is a digital holotype of behavior related to the dying process, and subsequent death, in chimpanzees. It describes the full story of an infant chimpanzee who contracted a respiratory disease and died in the wild. Jokro's mother, older sister, and other members of the Bossou community showed various forms of care toward the dying infant and her remains.

The 2003 respiratory disease epidemic at Bossou resulted in the loss of two more infants: Jimato, a 1.5-year-old male, and Veve, a 2.5-year-old female. Jimato's mother, Jire, continued to carry his corpse for 68 days, while Veve's mother, Vuavua, carried her daughter's body for 19 days. These two cases of dead-infant carrying closely resembled the original case of Jokro in 1992. We compiled our detailed observations of the three infant deaths at Bossou to extract common principles and discussed them in a possible cultural context (Biro et al. 2010; Biro 2011).

Thanatology is the study of death and dying. Evolutionary thanatology aims to bring a comparative perspective to the field, by drawing together evidence from a range of different species (Anderson et al. 2010; Gonçalves and Biro 2018). At present, we are facing a huge death toll caused by the COVID-19 outbreak. We are overwhelmed by the numbers and seldom think about what each individual death means. However, I believe that the case of every single individual is unique, essential, and important to provide us with opportunities to think about disease, death, and dying.

Long-running field research at Bossou was initiated in 1976 by Yukimaru Sugiyama (Sugiyama 2003; Sugiyama and Koman 1979; Matsuzawa et al. 2011; Yamakoshi 2011). Over the course of 45 years of study, from 1976 to 2020, we have recorded 58 chimpanzees at the site, and 11 confirmed cases and 6 probable cases of death among the Bossou community. I first encountered the death of a wild chimpanzee on January 17th 1988, during my second trip to Bossou. Guided by a bad smell, my colleague and I happened to come across the corpse of Npei, a 6.5-year-old male. We carefully measured his skull and bones and compared them with those from other field sites and captivity. In doing so, we learned about the physical development of wild chimpanzees from Npei's death (Matsuzawa et al. 1990). Many years later, I was faced with the death of a 58-year-old female named Velu. Based on my long-term observation of Velu and her offspring, I put together an account of her life story (Matsuzawa 2018). As in the case of these two chimpanzees, the story of Jokro that I summarized above allows me to keep a record of a life that I witnessed through my fieldwork.

Every single death provides us with a chance to think about the future. Chimpanzees are so like us. One 
chimpanzee, Jokro, lived for 2.5 years and died in the forest of Bossou. Facing the crisis caused by COVID-19, I wanted to reflect again on the chimpanzee way of life in order to also reflect on our own.

Acknowledgements I am particularly grateful to two old guides at Bossou who have passed away, Guanou Goumy and Tino Zogbila, both of whom were present when Jokro's story was documented in 1992. Without their help it would have been very difficult to keep such detailed records of the chimpanzees' behavior. I appreciate and admire the efforts of Miho Nakamura of ANC Productions Inc., Tokyo, who edited my long video recordings into a 19-min story. Several researchers contributed with field observations to the description of events in the 2003 epidemic: Tatyana Humle, Dora Biro, Claudia Sousa, Kathelijne Koops, Akino Kato-Watanabe, Yuu Mizuno, Misato Hayashi, Gen Yamakoshi, and Gaku Ohashi. Local guides at Bossou also offered invaluable help during the difficult period of the 2003 epidemic, in particular Jules Dore, Boniface Zogbila, Paquilé Chérif, and Pascal Goumy. I also thank our Guinean counterparts, Jeremie Koman, Tamba Tagbino, and Kabine Kante of DNRST in 1992, and Makan Kourouma and other colleagues of IREB in 2003. The Japanese embassy has been supporting the Kyoto University project from the beginning for decades: I appreciate the ambassadors and the officers. Long-running fieldwork in Bossou was initiated by Yukimaru Sugiyama in 1976. The initiative of KUPRI (Kyoto University Primate Research Institute) was passed from Sugiyama to the author and then to the next generation: Gen Yamakoshi, Gaku Ohashi, Naruki Morimura, and Misato Hayashi. In addition to Japanese researchers, foreign students joined the Bossou-Nimba field study since 1995: Tatyana Humle, Dora Biro, Claudia Sousa, Laura Martinez, Kimberly Hockings, Kathelijne Koops, Susana Carvalho, and the younger generation. The Bossou project has continued for 45 years from 1976 to 2020 and this is achieved by the international collaboration with Guinean authorities that are currently operated by Mon. Abdoulaye Yéro Baldé, Ministre de l'Enseignement Supérieur et de la Recherche Scientifique; Dr. Binko Mamady Toure, Secretaire General du Ministere; Dr. Mafory Bangoura, Directrice Générale de la Recherche Scientifique et de l'Innovation Technologique; Prof. Sékou Moussa Keita, Directeur Général du Centre d'Étude et de Recherche en Environnement; Dr. Ousmane Wora Diallo, Recteur de Centre Universitaire de N'Zérékoré, and Dr. Aly Gaspard Soumah, Directeur Géneral, Institut de Recherche Environnementale de Bossou (IREB). Financial support for preparing the manuscript came from MEXT-JSPS Grants \#24000001 and \#16H06283; LGP-U04, the Japan Society for the Promotion of Science (JSPS) Core-to-Core Program CCSN to the author. I also thank Dr. James Anderson, Dr. Satoshi Hirata, and Ms. Miho Nakamura for their valuable comments on the draft, and Dr. Tatyana Humle and Dr. Dora Biro for their efforts of reviewing and editing the English text.

\section{References}

Anderson JR, Gillies A, Lock LC (2010) Pan thanatology. Curr Biol 20:R349-R351

Biro D (2011) Chimpanzee mothers carry the mummified remains of their dead infants: three case reports from Bossou. In: Matsuzawa T, Humle T, Sugiyama Y (eds) The chimpanzees of Bossou and Nimba. Springer, Tokyo, pp 241-250

Biro D, Inoue-Nakamura N, Tonooka R, Yamakoshi G, Sousa C, Matsuzawa T (2003) Cultural innovation and transmission of tool use in wild chimpanzees: evidence from field experiments. Anim Cogn 6:213-223
Biro D, Humle T, Koops K, Sousa C, Hayashi M, Mastzuawa T (2010) Chimpanzee mothers at Bossou, Guinea, carry the mummified remains of the dead infants. Curr Biol 20:R351-R352

Boesch C (2008) Why do chimpanzees die in the forest?: the challenges of understanding and controlling for wild ape health. Am J Primatol 70:722-726

Gonçalves A, Biro D (2018) Comparative thanatology, an integrative approach: exploring sensory/cognitive aspects of death recognition in vertebrates and invertebrates. Phil Trans R Soc B 373:20170263. https://doi.org/10.1098/rstb.2017.0263

Goodall J (1986) The chimpanzees of Gombe: patterns of behavior. Belknap Press of Harvard University Press, Cambridge

Gorbalenya AE, Baker SC, Baric RS, de Groot RJ, Drosten C, Gulyaeva AA, Haagmans BL, Lauber C, Leontovich AM, Neuman BW, Penzar D, Perlman S, Poon LLM, Samborskiy D, Sidorov IA, Sola I, Ziebuhr J (2020) Severe acute respiratory syndromerelated coronavirus: the species and its viruses-a statement of the Coronavirus Study Group. bioRxiv Prepr. https://doi. org/10.1101/2020.02.07.937862

Hanamura S, Kiyono M, Nakamura M, Sakamaki T, Itoh N, Zamma K, Kitopeni R, Matsuzmura M, Nishida T (2006) A new code of observation employed at Mahale prevention against a flu-like disease. Pan Afr News 13:13-16

Hosaka K (1995) Mahale: a single flu epidemic killed at least 11 chimps. Pan Afr News 2:3-4

Humle T (2011) The 2003 epidemic of a flu-like respiratory disease at Bossou. In: Matsuzawa T, Humle T, Sugiyama Y (eds) The chimpanzees of Bossou and Nimba. Springer, Tokyo, pp $325-333$

Inoue-Nakamura N, Matsuzawa T (1997) Development of stone tool use by wild chimpanzees (Pan troglodytes). J Comp Psychol 111:159-173. https://doi.org/10.1037/0735-7036.111.2.159

Kaur T, Singh J, Tong S, Humphrey C, Clevenger D, Tan W, Szekely B, Wang Y, Li Y, Muse EA, Kiyono M, Hanamura S, Inoue E, Nakamura M, Huffman MA, Jiang B, Nishida T (2008) Descriptive epidemiology of fatal respiratory outbreaks and detection of a human-related metapneumovirus in wild chimpanzees (Pan troglodytes) at Mahale Mountains National Park, Western Tanzania. Am J Primatol 70:755-765. https://doi.org/10.1002/ajp.20565C

Köndgen S, Kühl H, N'Goran PK, Walsh PD, Schenk S, Ernst N, Biek R, Formenty P, Mätz-Rensing K, Schweiger B, Junglen S, Ellerbrok H, Nitsche A, Briese T, Lipkin WI, Pauli G, Boesch C, Leendertz FH (2008) Pandemic human viruses cause decline of endangered great apes. Cur Biol 18:260-264. https://doi. org/10.1016/j.cub.2008.01.012

Leendertz SAJ, Wich SA, Ancrenaz M, Bergl RA, Gonder MK, Humle T, Leendertz FH (2017) Ebola in great apes: current knowledge, possibilities for vaccination, and implications for conservation and human health. Mammal Rev 47:98-111. https://doi.org/10.1111/ mam. 12082

Leroy EM, Kumulungui B, Pourrut X, Rouquet P, Hassanin A, Yaba P, Délicat A, Paweska JT, Gonzalez JP, Swanepoel R (2005) Fruit bats as reservoirs of Ebola virus. Nature 438:575-576

Lonsdorf EV, Travis D, Pusey AE, Goodall J (2006) Using retrospective health data from the Gombe chimpanzee study to inform future monitoring efforts. Am J Primatol 68:897-908

Matsuzawa T (1994) Field experiments on use of stone tools by chimpanzees in the wild. In: Wrangham RW, McGrew WC, de Waal FBM, Heltne PG (eds) Chimpanzee cultures. Harvard University Press, Cambridge, pp 351-370

Matsuzawa T (1997) The death of an infant chimpanzee at Bossou, Guinea. Pan Afr News 4:4-6

Matsuzawa T (2006) Bossou: 30 years. Pan Afr News 13:16-19

Matsuzawa T (2011) Log doll: pretense in wild chimpanzees. In: Matsuzawa T, Humle T, Sugiyama Y (eds) The chimpanzees of Bossou and Nimba. Springer, Tokyo, pp 131-135 
Matsuzawa T (2018) Chimpanzee Velu: the wild chimpanzee who passed away at the estimated age of 58. Primates 59:107-111

Matsuzawa T, Sakura O, Kimura T, Hamada Y, Sugiyama Y (1990) Case report on the death of a wild chimpanzee (Pan troglodytes verus). Primates 31:635-641

Matsuzawa T, Humle T, Koops K, Biro D, Hayashi M, Sousa C, Mizuno Y, Kato A, Yamakoshi G, Ohashi G, Sugiyama Y, Kourouma M (2004) Wild chimpanzees at Bossou-Nimba: deaths through a flu-like epidemic in 2003 and the Green Corridor Project. Primate Res 20:45-55 (in Japanese with English abstract)

Matsuzawa T, Humle T, Sugiyama Y (eds) (2011) The chimpanzees of Bossou and Nimba. Springer, Tokyo, p 465

Negrey JD, Reddy RB, Scully EJ, Phillips-Garcia S, Owens LA, Langergraber KE, Mitani JC, Thompson ME, Wrangham RW, Muller MN, Otali E, Machanda Z, Hyeroba D, Grindle KA, Pappas TE, Palmenberg AC, Gern JE, Goldberg TL (2019) Simultaneous outbreaks of respiratory disease in wild chimpanzees caused by distinct viruses of human origin. Emerg Microb Infec 8:139-149. https://doi.org/10.1080/22221751.2018.1563456

Saéz AM, Weiss S, Nowak K, Lapeyre V, Zimmermann F, Düx A, Kühl HS, Kaba M, Regnaut S, Merkel K, Sachse A, Thiesen U, Villányi L, Boesch C, Dabrowski PW, Radonić A, Nitsche A, Leendertz SAJ, Petterson S, Becker S, Krähling V, Couacy-Hymann E, Akoua-Koffi C, Weber N, Schaade L, Fahr J, Leendertz FH (2015) Investigating the zoonotic origin of the West African Ebola epidemic. EMBO Mol Med 7:17-23. https://doi.org/10.15252/ emmm. 201404792

Schofield D, Nagrani A, Zisserman A, Hayashi M, Matsuzawa T, Biro D, Carvalho S (2019) Chimpanzee face recognition from videos in the wild using deep learning. Sci Adv 5:eaaw0736. https://doi. org/10.1126/sciadv.aaw0736

Scully EJ, Basnet S, Wrangham RW, Muller MN, Otali E, Hyeroba D, Grindle KA, Pappas TE, Thompson ME, Machanda Z, Watters KE, Palmenberg AC, Gern JE, Goldberget TL (2018) Lethal respiratory epidemic in wild chimpanzees associated with human rhinovirus C. Emerg Infect Dis 24:267-274. https://doi.org/10.3201/ eid2402.170778
Sugiyama Y (2003) Demographic parameters and life history of chimpanzees at Bossou, Guinea. Am J Phys Anthropol 124:154-165. https://doi.org/10.1002/ajpa.10345

Sugiyama Y, Koman J (1979) Social structure and dynamics of wild chimpanzees at Bossou, Guinea. Primates 20:323-339

Thompson ME, Machanda ZP, Scully EJ, Enigk DK, Otali E, Muller MN, Goldberg TL, Chapman CA, Wrangham RW (2018) Risk factors for respiratory illness in a community of wild chimpanzees (Pan troglodytes schweinfurthii). R Soc Open Sci 5:180840. https ://doi.org/10.1098/rsos.180840

Wallis J, Lee DR (1999) Primate conservation: the prevention of disease transmission. Int J Primatol 20:803-826

Wang M, Yan M, Xu H, Liang W, Kan B, Zheng B, Chen H, Zheng H, Xu Y, Zhang E, Wang H, Ye J, Li G, Li M, Cui Z, Liu YF, Guo RT, Liu XN, Zhan LH, Zhou DH, Zhao A, Hai R, Yu D, Guan $\mathrm{Y}, \mathrm{Xu}$ J (2005) SARS-CoV infection in a restaurant from Palm Civet. Emerg Infect Dis 11:1860-1865. https://doi.org/10.3201/ eid1112.041293

Wang LF, Shi Z, Zhang S, Field H, Daszak P, Eaton BT (2006) Review of bats and SARS. Emerg Infect Dis 12:1834-1840. https://doi. org/10.3201/eid1212.060401

Williams JM, Lonsdorf EV, Wilson ML et al (2008) Causes of death in the Kasekela chimpanzees of Gombe National Park. Tanzania Am J Primatol 70:766-777. https://doi.org/10.1002/ajp.20573

Yamakoshi G (2011) The "Prehistory" before 1976: Looking back on three decades of research on Bossou chimpanzees. In: Matsuzawa T, Humle T, Sugiyama Y (eds) The chimpanzees of Bossou and Nimba. Springer, Tokyo, pp 35-44

Publisher's Note Springer Nature remains neutral with regard to jurisdictional claims in published maps and institutional affiliations. 